\title{
Tobacco plain packaging, human rights and the object and purpose of international trade mark protection, Genevieve Wilkinson*
}

\section{INTRODUCTION}

Intellectual property and human rights developed separately and they remain separate from each other despite increasing interactions between them that can sometimes result in conflict. However interpretive tools in public international law, such as reference to the object and purpose of an agreement, can increase the likelihood of harmonious interpretation between separate fields of law. ${ }^{1}$ The visibility of intersections between intellectual property and human rights increased following the introduction of the World Trade Organisation (WTO) Agreement on Trade Related Aspects of Intellectual Property (TRIPS). ${ }^{2}$ Human rights concerns were used persuasively to address concerns about the impact of the patent provisions of TRIPS on access to medicine ${ }^{3}$ and remain relevant to that debate as well as others such as the protection of traditional knowledge for Indigenous Peoples. ${ }^{4}$ More recently human rights arguments focusing on the impact of more expansive protection of copyright on privacy, freedom of expression and the right to a fair trial featured in debate surrounding the ratification of ACTA in a number of countries. ${ }^{5}$ Concerns about the human right to education remain relevant to the protection of copyright in educational materials. ${ }^{6}$ The potential role of human rights in the context of trade marks has become increasingly apparent as owners of tobacco related trade marks assert their right against governments, attempting to limit their programs to reduce tobacco consumption and improve health outcomes. ${ }^{7}$

This chapter considers the object and purpose of key international treaties regulating trade mark law from a human rights perspective. It uses the example of tobacco plain packaging legislation to argue that trade mark law can engage important human rights issues and a human rights approach is relevant to an analysis of the object and purpose of TRIPS and the Paris Convention. Different interpretations of the object and purpose of TRIPS permit or exclude a human rights perspective. This can be contrasted to an interpretation of the object and purpose of the Paris Convention. Disputes regarding tobacco plain packaging provide a valuable case study to consider the relationship between human rights and trade marks, engaging questions about human rights to health, freedom of expression, development and protection of moral and material interests in intellectual property itself. The important public health arguments raised by disputes regarding

\footnotetext{
* University of Technology Sydney. This research was undertaken with the research support of the Quentin Bryce Doctoral Scholarship. The author would like to thank Natalie Stoianoff and Beth Goldblatt for their generous feedback and encouragement and acknowledge comments from the participants at the ATRIP Annual Congress of 2017, particularly the insightful comments of Professor Susy Frankel on earlier drafts of this chapter.

${ }^{1}$ Henning Grosse Ruse-Khan, The Protection of Intellectual Property in International Law (Oxford University Press 2016) 34.

${ }^{2}$ Marrakesh Agreement Establishing the World Trade Organization, (opened for signature 15 April 1994, entered into force 1 January 1995), 1867 UNTS 3 annex 1C (Agreement on Trade-Related Aspects of Intellectual Property Rights) (TRIPS)

${ }^{3}$ Noah Novogrodsky, 'After AIDS ' [2013] 14 Melbourne University Law Review 643, 650.

${ }^{4}$ Susy Frankel 'Using Intellectual Property Rules to Support the Self-Determination Goals of Indigenous People' in Christophe Geiger (ed), Research handbook on human rights and intellectual property (Edward Elgar 2015) 645-648.

${ }^{5}$ Peter K. Yu, Six Secret (and Now Open) Fears of ACTA (2011) 64 SMU Law Review 975, 1033-1035, 1050-1059.

${ }^{6}$ Laurence R Helfer and Graeme W Austin, Human Rights and Intellectual Property: Mapping the Global Interfaces, (Cambridge University Press 2011) 316-363. Lawrence Liang, "Paternal and defiant access: copyright and the politics of access to knowledge in the Delhi University photocopy case" (2017) 1(1) Indian Law Review 36, 43.

7 Samuel Murumba, 'Foxes and Hedgehogs at the Intersection of Human Rights and Intellectual Property' (2012) 38 Monash University Law Review 119.
} 
tobacco plain packaging legislation in the WTO (the WTO Disputes) can be viewed from the perspective of the human right to the highest attainable standard of health. ${ }^{8}$ Despite this, a human rights perspective has not been the emphasis of the arguments made by Australia and was not considered by the Panel that determined the WTO Disputes. ${ }^{9}$ This chapter will argue that the object and purpose expressed in the preamble and articles 7 and 8 of TRIPS engages human rights concerns when it is applied to the tobacco plain packaging dispute.

\section{FRAGMENTATION}

\subsection{Importance of object and purpose in the context of fragmentation}

In the absence of explicit incorporation of human rights in intellectual property agreements, there needs to be an interpretive link for human rights to be considered in disputes about trade mark law in international law. Although human rights agreements and intellectual property agreements often have substantially different subject matter, interpretive rules in public international law can be relevant to understanding the relationship between the agreements where they appear to conflict with each other. ${ }^{10}$ This may assist states to observe their obligations under treaties binding upon them in good faith. ${ }^{11}$ The potential for conflicts resulting from the fragmentation of international law has been recognised in the international community. ${ }^{12}$ Interpretive tools can also be useful for addressing fragmentation between intellectual property and other fields of law. ${ }^{13}$ Object and purpose is a relevant tool for interpretation of treaties which can be useful for identifying other agreements that may have overlapping subject matter and be relevant to the interpretative exercise. These agreements can constitute relevant rules of international law between the parties and be used by treaty interpreters to address fragmentation. ${ }^{14}$ Recognition of other relevant international agreements in treaty interpretation increases the likelihood that treaty interpretation in one field of international law will be harmonious with other relevant fields of international law. This is important where the subject matter of different treaties is largely separate but the operation of the terms of the treaty impacts on the operation of the separate treaty.

The fields of intellectual property and human rights are examples of two fields of law that have been generally considered to be separate. One of the reasons that the potential link between the fields is not explicitly relevant is their different institutional development. This article focuses on human rights protections found in the International Covenant on Economic, Social and Cultural Rights

\footnotetext{
${ }^{8}$ Ibid. Henning Grosse Ruse-Khan (n1) 255. Ernst-Ulrich Petersmann, 'How to Reconcile Health Law and Economic Law with Human Rights - Administration of Justice in Tobacco Control Disputes' [27] (2015) 10 Asian Journal of WTO \& International Health Law \& Policy 27.

9 Panel Report, Australia - Certain Measures Concerning Trademarks, Geographical Indications and Other Plain Packaging Requirements Applicable to Tobacco Products and Packaging, WTO Doc WT/DS435/R, WT/DS441/R, WT/DS458/R, WT/DS467/R (28 June 2018) (Australia - Plain Packaging Measures). See also Australian Department of Foreign Affairs and Trade, Integrated Executive Summary of Australia's Submissions, 23 March 2016, <http://dfat.gov.au/trade/organisations/wto/wto-disputes/Documents/integrated-executive-summaryaus-submissions-tobacco-plain-packaging-ds435-441-458-467.pdf> (accessed 8 May 2018) (Summary of Arguments).

${ }^{10}$ Ruse-Khan (n 1) 34-44.

${ }^{11}$ Vienna Convention on the Law of Treaties (opened for signature 23 May 1969, entered into force 27 January 1980) 1155 UNTS 331 (VCLT) art 26 codifies the pacta sunt servanda obligation.

12 International Law Commission, 'Fragmentation of International Law: Difficulties Arising from the Diversification and Expansion of International Law' (Report of the Study Group of the International Law Commission) (13 April 2006) UN Doc A/CN.4/L.682.

${ }^{13}$ Ruse-Khan (n 1) 31-66.

${ }^{14}$ Henning Grosse Ruse-Khan identifies VCLT Article 31(3)(c) as part of his interpretive tool box for addressing fragmentation: Ruse-Khan (n 1) 34-36.
} 
(ICESCR)..$^{15}$ The relevant treaty making body is the Committee on Economic, Social and Cultural Rights (CESCR). Multilateral trade marks protection was initially agreed through the Paris Convention for the Protection of Industrial Property. ${ }^{16}$ In 1967 the World Intellectual Property Organisation (WIPO) became responsible for the administration of the Paris Convention. ${ }^{17}$ The Paris Union continued to discuss revisions to the Agreement. Although WIPO is a United Nations institution, it remained separate from the United Nations institutions that were responsible for human rights. These developed following the adoption of the Universal Declaration of Human Rights (UDHR) in $1948 .{ }^{18}$ The deliberations of the negotiating teams responsible for the UDHR and ICESCR did not appear to recognise the significance of the potential overlap between the fields. ${ }^{19}$ That significance did not crystallise until the development of a separate regime for multilateral intellectual property protection in the World Trade Organisation as a result of the TRIPS Agreement. ${ }^{20}$ Although there is some institutional cooperation between WIPO and WTO, ${ }^{21}$ there is very little interaction between the TRIPS Council and human rights institutions. ${ }^{22}$

United Nations human rights institutions, including CESCR, operate quite separately from the WTO and the TRIPS Council but also from the World Intellectual Property Organisation (WIPO). ${ }^{23}$ WIPO remains important for the development of new multilateral intellectual property standards ${ }^{24}$ but the enforcement mechanisms provided by TRIPS have meant that the WTO has been the institutional focal point for interpretation of intellectual property standards. ${ }^{25}$ TRIPS is interpreted pursuant to the Dispute Settlement Understanding (DSU) by the Dispute Settlement Body (which includes panels and the Appellate Body) although disputes can be resolved through processes of good offices, mediation and conciliation before they reach adjudication. ${ }^{26}$ Important features of the process are the remedies available to complainants when breaches of TRIPS are established. ${ }^{27}$ These include retaliatory economic sanctions. ${ }^{28}$ The threat of sanctions of this nature strengthens the likelihood

\footnotetext{
${ }^{15}$ International Covenant on Economic, Social and Cultural Rights (opened for signature 16 December 1966, entered into force 3 January 1976) 993 UNTS 3 (ICESCR).

${ }^{16}$ Paris Convention for the Protection of Industrial Property (opened for signature, entered into force 6 July 1884) 20 March 1883, 828 UNTS 305, revised at Stockholm 14 July 1967, amended 28 September 1979.

17 Paris Convention, Stockholm Revision Act art 15(1)(a).

18 Universal Declaration of Human Rights (adopted 10 December 1948) UNGA Res 217 A(III) (UDHR)

${ }^{19}$ Lea Shaver 'The Right to Science and Culture' (2010) Wisconsin Law Review 121, 149-151.

${ }^{20}$ Laurence Helfer 'Regime Shifting: The TRIPs Agreement and New Dynamics of International Intellectual Property Lawmaking,' (2004) 29 Yale International Law Journal 1, 6.

${ }^{21}$ Agreement Between the World Intellectual Property Organization and the World Trade Organization (concluded in Geneva on December 22, 1995, entered into force 1 January 2006) 35 ILM 754.

22 Klaus D. Beiter, Establishing Conformity Between TRIPS and Human Rights: Hierarchy in International Law, Human Rights Obligations of the WTO and Extraterritorial State Obligations Under the International Covenant on Economic, Social and Cultural Rights, in Hanns Ullrich, Reto M. Hilty, Matthias Lamping and Joseph Drexel eds. TRIPS Plus 20: From Trade Rules to Market Principles (Springer 2016) 497-8.

23 ibid.

${ }^{24}$ For a recent example, see Marrakesh Treaty to Facilitate Access to Published Works for Persons Who Are Blind, Visually Impaired, or Otherwise Print Disabled (adopted June 27, 2013, entered into force September 30, 2016) WIPO Doc. VIP/DC/8.

${ }^{25}$ Laurence Helfer, 'Human Rights and Intellectual Property: Mapping an Evolving and Contested Relationship' in Rochelle C. Dreyfuss and Justine Pila (eds), The Oxford Handbook of Intellectual Property Law (Oxford University Press 2018) 121-122.

${ }^{26}$ WTO, Dispute Settlement Rules: Understanding on Rules and Procedures Governing the Settlement of Disputes, Marrakesh Agreement Establishing the World Trade Organization, (agreed 15 April 1994, entered into force 1 January 1995) 1869 UNTS 40 art 5.1 (DSU).

27 DSU art 22.

${ }^{28}$ DSU art 22.2.
} 
that TRIPS Agreement standards will be observed. ${ }^{29}$ In contrast, human rights claims are governed under separate mechanisms which emphasise consensus-based compliance. ${ }^{30}$ Although the Paris Convention provides for dispute resolution through the International Court of Justice, this mechanism has never been engaged. ${ }^{31}$

Increasing intersections between the fields mean that the doctrinal relationship between them can be important. Fragmentation between different fields of international law can mean that states are bound by conflicting obligations which cannot be effectively addressed by interpretive rules such as lex posterior ${ }^{32}$ and lex specialis. ${ }^{33}$ However, Article 31 of the Vienna Convention on the Law of Treaties also identifies other tools for interpretation which permit good faith interpretation of treaties that bind states. This article codifies rules of interpretation found in customary international law. It provides that good faith interpretation of terms of a treaty shall be in light of the object and purpose of a treaty as well as the ordinary meaning of the terms in their context. Article 31 provides further guidance for this interpretive exercise. The text, including preamble and annexes, is part of the interpretative context. ${ }^{34}$ This context also includes agreements made in connection with the conclusion of the treaty. ${ }^{35}$ These can be made by all of the parties or made by one or more parties and accepted as related to the treaty by all parties. ${ }^{36}$ Article 31(3) identifies further matters to be considered which include subsequent agreements or practice relevant to the interpretation and relevant rules of international law applicable in the relations between parties. In addition to being part of interpretative exercise set out in Article 31(1), object and purpose can be important to the latter consideration as it indicates rules that are likely to be relevant.

\subsection{Why are human rights and trade marks fragmented}

There are a number of reasons that human rights and trade marks are considered to be separate fields of international law. The agreements that enshrine legal obligations for states in each field are separate and do not explicitly reference the other field. ICESCR provides possible protection for trade marks. ${ }^{37}$ Right to property protection that may apply to trade marks can be found in some domestic constitutions and regional instruments. ${ }^{38}$ However, despite this lack of direct crossover between the relevant texts, the instrumental nature of trade marks means that they can be significant to human rights. ${ }^{39}$ In addition to article 15 and right to property considerations, links

\footnotetext{
${ }^{29}$ Helfer (n 20) 2; Murumba refers to command sanction nature of global intellectual property: Murumba (n 7) 133; Matthew Kennedy WTO Dispute Settlement and the TRIPS Agreement. Vol. 24. (Cambridge University Press 2016).

${ }^{30}$ Rhona K Smith Textbook on International Human Rights ( $7^{\text {th }}$ edn, Oxford University Press 2016) 171.

${ }^{31}$ Sam Ricketson The Paris Convention for the Protection of Industrial Property (Oxford University Press 2015) 323.

32 VCLT art 30. Lex posterior derogat legi priori refers to the principle that where all parties to a treaty are also parties to a later treaty on the same subject, provisions in the later treaty supersede provisions in the earlier treaty: International Law Commission, Fragmentation of International Law: Difficulties Arising from the Diversification and Expansion of International Law (Report of the Study Group of the International Law Commission - Conclusions, 18 July 2006, UN Doc A/CN.4/L.702) 17.

${ }^{33}$ Henning Grosse Ruse-Khan, 'A Conflict-Of-Laws Approach to Competing Rationalities in International Law: The Case of Plain Packaging between Intellectual Property, Trade, Investment and Health' (2013) 9(2) Journal of Private International Law 308, 309.

${ }^{34}$ VCLT art 31(1).

${ }^{35}$ VCLT art 31(2).

${ }^{36}$ VCLT art 31(3).

37 ICESCR art 15(1)(c).

38 Peter K. Yu 'The Anatomy of the Human Rights Framework for Intellectual Property' (2016) 69 SMU Law Review 37, 94-95; Helfer and Austin (n 6) 212-220.

${ }^{39}$ For example, the role of trade marks in detecting counterfeit goods has implications for the human right to health: Duncan Matthews, 'Counterfeiting and Public Health' in Christophe Geiger (ed), Criminal Enforcement of Intellectual Property: A Handbook of Contemporary Research (Edward Elgar 2011) 42, 45-58.
} 
between trade marks and human rights can be seen in the case of freedom of expression and the human right to health. ${ }^{40}$

Even more so than patents and copyright, trade mark law has been generally considered to address subject matter that is substantially different to human rights. ICESCR Article 15(1)(c) provides that everyone should benefit from the protection of the moral and material rights to any literary, artistic and scientific production they have created. It has been characterised as an alternative system of protection for intellectual property. ${ }^{41}$ It can be used to justify some human rights protection for patents and copyright, but it is not generally considered to apply to trade marks. ${ }^{42}$ Where there is human rights protection for property, this may provide limited protection for the owners of trade marks. ${ }^{43}$ However, although this protection is available in some regional systems and domestic constitutions, the right to property has not been translated into a binding obligation in the key multilateral human rights agreements. ${ }^{44}$ Trade mark rights are not generally considered to be human rights. This does not mean that human rights are not relevant to the operation of agreements concerning trade mark law. This chapter considers the human rights implications attempts to restrict states in implementing tobacco plain packaging legislation. These attempts have been staged in domestic, bilateral and multilateral environments. Their impact is both direct and indirect as these attempts can have a chilling impact on regulation in states where the legislation has been contemplated but not introduced.

\section{HUMAN RIGHTS CONSIDERATIONS AND THE OBJECT AND PURPOSE OF TRIPS}

\subsection{The object and purpose of TRIPS and human rights}

This section will argue that each of the preamble, article 7 and article 8 permit consideration of states' binding human rights obligations and are relevant to the object and purpose of TRIPS. The object and purpose of TRIPS is a relevant interpretative tool when WTO disputes require interpretation of specific provisions of TRIPS. ${ }^{45}$ The WTO Dispute Settlement Body recognises the relevance of customary rules of interpretation of public international law to their deliberations. ${ }^{46}$ This is interpreted to mean that the interpretative principles included in the Vienna Convention on the Law of Treaties apply. ${ }^{47}$ Article $31(1)$ provides that ' $[A]$ treaty shall be interpreted in good faith in accordance with the ordinary meaning to be given to the terms of the treaty in their context and in the light of its object and purpose. ${ }^{48}$ The object and purpose of an agreement is often found in the

\footnotetext{
${ }^{40}$ Ruse-Khan recognises a relationship between trade marks, plain packaging and the right to health: see generally Ruse-Khan (n 33). Helfer and Austin recognise the relationship between freedom of expression and trade marks (n 6) 283-312.

${ }^{41}$ Committee on Economic, Social and Cultural Rights, The Right of Everyone to Benefit from the Protection of the Moral and Material Interests Resulting from Any Scientific, Literary or Artistic Production of which He or She is the Author (article 15, paragraph 1 (c), of the Covenant), General Comment No. 17 (2005), U.N. ESCOR, 35th Sess., U.N. Doc. E/C.12/GC/17 (2006); Ruse-Khan (n 1) 212.

$42 \mathrm{Yu}$ (n 38) 85-95.

${ }^{43}$ Megan M. Carpenter, 'Trademarks and Human Rights: Oil and Water - Or Chocolate and Peanut Butter' (2009) 99 Trademark Reporter 892, 915-916.

44 Ibid.

${ }^{45}$ Frankel explains how international law relevant to public health, including the Framework Convention on Tobacco Control, can be relevant to a VCLT-based interpretation of the meaning of human health in the TRIPS Agreement: Susy Frankel, 'The WTO's Application of 'the Customary Rules of Interpretation of Public International Law' to Intellectual Property' (2006) 46 Virginia Journal of International Law 365, 420-421. See also Ruse-Khan (n 1) 34-36.

${ }^{46}$ DSU art 3.2.

47 United States-Import Prohibition of Certain Shrimp and Shrimp Products, WTO Appellate Body, WT/DS58/AB/R (October 12, 1998).

${ }^{48}$ VCLT art 31. The VCLT is used to guide treaty interpretation in the WTO: DSU art 3.2.
} 
preamble of an agreement. ${ }^{49}$ The significance of articles 7 and 8 as an expression of the object and purpose of TRIPS that is relevant to the interpretation of each provision of the TRIPS Agreement was emphasised by members of the WTO in the Doha Declaration on TRIPS and Public Health. ${ }^{50}$ In addition to the ordinary meaning of terms in their context and the object and purpose of the treaty, Article 31 recognises the interpretative relevance of subsequent agreements and practice in relation to the treaty and 'any relevant rules of international law applicable in the relations between the parties. ${ }^{51}$ The object and purpose of a treaty can guide identification of relevance of these rules of international law in specific interpretative exercises.

The Preamble of TRIPS engages human rights considerations because, along with its objectives of protection and enforcement of intellectual property rights, it recognises 'the underlying public policy objectives of national systems for the protection of intellectual property, including developmental and technological objectives. ${ }^{52}$ The importance of harmonious interpretation of state obligations in international law means that it can be assumed that a relevant underlying public policy objective of intellectual property protection system complies with other international obligations, including binding human rights obligations..$^{53}$ Importantly these obligations are not only obligations to respect human rights but also obligations to protect and fulfil human rights. ${ }^{54}$ Some of these protection and fulfilment obligations overlap with the object and purpose of TRIPS that is suggested by Articles 7 and 8 of TRIPS.

Article 7 explicitly acknowledges that 'protection and enforcement of intellectual property rights should contribute.. to a balance of rights and obligations.' Importantly protection and enforcement should also contribute 'in a manner conducive to social and economic welfare.' Other relevant objectives to which protection and enforcement should contribute are technological innovation, transfer and dissemination of technology and production and use of technological knowledge. ${ }^{55}$ Part 1 of Article 8, the principles provision of TRIPS, identifies specific interests that are relevant considerations for States in the implementation of TRIPS, many of which are relevant to human rights concerns. These include necessary public health and nutrition protection measures and public interest in sectors of vital importance to Member States' socio-economic and technological development. ${ }^{56}$ The extent to which the final part of Article 8.1, 'provided such measures are

\footnotetext{
${ }^{49}$ Isabelle Buffard and Karl Zemanek 'The “Object and Purpose” of a Treaty: An Enigma?' (1998) 3 Austrian Review of International \& European Law 311, 322

${ }^{50}$ WTO Ministerial Conference, Declaration on the TRIPS Agreement and Public Health Adopted on 14 November 2001, WTO Doc WT/MIN(01)/DEC/2 (20 November 2001) (Doha Declaration). Voon and Mitchell argue that this constitutes a 'subsequent agreement between the parties regarding the interpretation of the treaty or the application of its provisions' which VCLT Article 31(3)(a) directs treaty interpreter to consider: Tania Voon and Andrew D. Mitchell, 'Implications of WTO law for plain packaging of tobacco products' in Tania Voon, Andrew D. Mitchell and Jonathan Liberman (eds), Public Health and Plain Packaging of Cigarettes: Legal Issues (Edward Elgar 2012) 122.

51 VCLT art 31(3).

52 TRIPS preamble.

53 International Law Commission, Fragmentation of International Law: Difficulties Arising from the Diversification and Expansion of International Law (Report of the Study Group of the International Law Commission - Conclusions, 18 July 2006, UN Doc A/CN.4/L.702) 8. Yu recognises the importance of human rights as exogenous limits to intellectual property rights: Peter K. Yu, 'The Objectives and Principles of the TRIPS Agreement' (2009) 46 Houston Law Review 979, 1008.

${ }^{54}$ United Nations Committee on Economic, Social and Cultural Rights (CESCR), General Comment No. 14: The Right to the Highest Attainable Standard of Health (Art 12 of the Covenant), 11 August 2000, E/C.12/2000/4. [33].

${ }^{55}$ Yu separates Article 7 into five separate objectives: Yu (n 53) 1000.

${ }^{56}$ TRIPS art 8(1). TRIPS art 8(2) also provides for further balancing exercises to occur in circumstances restraining trade or technology transfer that constitute an abuse of rights.
} 
consistent with the provisions of this Agreement,' restricts the ability of Member States to rely on this article in developing intellectual property policy that emphasises national interests remains contested. ${ }^{57}$ Correa argues that the preamble and Article 7 are provisions that interpretation of Article 8 should be consistent with, so social and economic welfare and a balance of rights and obligations should be taken into account. ${ }^{58} \mathrm{Yu}$ recognises that in any dispute settlement proceedings there are many supportive links between human rights agreements and the objectives and principles identified in Article 7 and 8, including rights to life, food, health, education, self-determination, freedom of expression, cultural participation and development, and the benefits of scientific progress. ${ }^{59}$ Importantly, the relevant human rights provisions will vary, depending on the circumstances of the case and policy measures need to be effective in meeting their objectives. ${ }^{60}$

\subsection{The object and purpose of the Paris Convention and human rights}

In contrast to TRIPS, the Paris Convention does not contain a preamble and there are no specific clauses to guide object and purpose clauses analogous to Article 7 and 8 . Our understanding of object and purpose can be guided by the title, which recognises that the agreement is for the protection of industrial property for foreign nationals of member states. ${ }^{61}$ In comparison to the recognition of underlying public policy in TRIPS as well as the developmental and technological objectives of the agreement, the object and purpose of the Paris Convention appears very narrow. ${ }^{62}$ Like TRIPS, there is no explicit recognition of human rights in the Paris Convention.

The Paris Convention does permit recognition of public interest concerns in some provisions which engage human rights concerns. For example, Geiger and Pontes link the permissible exceptions for the requirement of states to register marks already registered in other members of the Paris Union to fundamental rights considerations of freedom of expression and freedom to conduct business. ${ }^{63}$ They argue that, in a European context, restrictions on registration pursuant to Article 6 quinquies (b) of the Paris Convention are subject to fundamental rights obligations and generally consistent with those obligations. ${ }^{64}$ However, there are broader freedom of expression considerations, which may be engaged where there is a mixture of commercial and political or artistic opinion and political or artistic message depends on registration. ${ }^{65}$ Human rights obligations that constitute 'relevant rules of international law applicable in the relations between the parties' could be argued in disputes regarding the Paris Convention that are brought within the jurisdiction of the International Court of Justice. ${ }^{66}$ The recognition of a right to benefit from science and culture in Article 15(1)(c) of ICESCR might be used to argue the relevance of that agreement to interpretation of provisions of the Paris Convention: Article 31(3)(c). If human rights obligations and Paris Convention obligations were

\footnotetext{
${ }^{57}$ Susy Frankel and Daniel J. Gervais, 'Plain Packaging and the Interpretation of the TRIPS Agreement' (2013) 46(5) Vanderbilt Journal of Transnational Law 1149, 1202-3; Yu (n 53) 1014-5.

${ }^{58}$ Yu (n 53) 1014 citing Carlos Correa, Trade Related Aspects of Intellectual Property Rights: A Commentary on the TRIPS Agreement, (Oxford University Press 2007) 104.

${ }^{59} \mathrm{Yu}$ (n 53) 1037.

${ }^{60}$ Hannu Wager and Jayashree Watal, 'Human Rights and International Intellectual Property Law' in Christophe Geiger (ed), Research Handbook on Human Rights and Intellectual Property. (Edward Elgar Publishing, 2015) 149-172, 159.

${ }^{61}$ Ricketson (n 31) 148-9.

62 ibid, 150.

${ }^{63}$ Christophe Geiger and Leonardo Machado Pontes, 'Trade Mark Registration, Public Policy, Morality and Fundamental Rights' Centre for International Intellectual Property Studies (CEIPI) Research Paper No. 2017-01. <https://ssrn.com/abstract=3009170> accessed 22 November 2011.

64 ibid.

65 ibid.

${ }^{66}$ VCLT art 31(3)(c).
} 
argued to be in conflict this could engage questions of hierarchy between the relevant agreements. ${ }^{67}$ To date, the jurisdiction of the International Court of Justice in relation to the Paris Convention has not been invoked. ${ }^{68}$

TRIPS Article 2.1 provides that member states 'shall comply with Articles 1 through 12 , and Article 19 , of the Paris Convention.' Human rights could also be relevant to interpretation of the Paris Convention in WTO Dispute Settlement processes because the object and purpose of TRIPS will apply in that interpretative exercise. ${ }^{69}$ This object and purpose of TRIPS could engage human rights considerations for the reasons set out above.

\section{ARE HUMAN RIGHTS OBLIGATIONS RELEVANT TO PLAIN PACKAGING?}

\subsection{What is Australian Plain Packaging Legislation and how has it been disputed?}

This section considers the relevance of human rights obligations to Australia's plain packaging legislation which has been the subject of several disputes in the WTO. The legislation has been alleged not to comply with provisions of TRIPS, including incorporated provisions of the Paris Convention, and the separate WTO agreement on Technical Barriers to Trade. ${ }^{70}$ The previous section has established that human rights obligations can be relevant to the object and purpose of TRIPS. However, the relevance of human rights will necessarily depend on the nature of the dispute. ${ }^{71}$ Plain packaging legislation engages a range of human rights considerations including the right to health, the right to freedom of expression and the right to benefits of science and culture. Some of these are relevant to the WTO Disputes.

Australia was the first in the world to completely restrict tobacco advertising on packaging when it introduced tobacco plain packaging legislation in 2011. Packaging has been characterised as one of the last vehicles for tobacco advertising and has been established to influence the initiation of tobacco consumption. ${ }^{72}$ Tobacco consumption has been characterised as a global health epidemic. ${ }^{73}$ Initiation of tobacco consumption is particularly relevant to young smokers who have been identified as a target market by tobacco companies. ${ }^{74}$ Tobacco consumption has significant negative consequences for the right to health. This was recognised multilaterally when states agreed to the World Health Organisation (WHO) Framework Convention on Tobacco Control (FCTC). ${ }^{75}$ As part of the FCTC, member states participate in the governing body, the Conference of Parties (COP). One of the functions of the COP is to adopt guidelines for certain provisions of the agreement.

Article 11 of the FCTC requires parties to the treaty to adopt and implement effective packaging and labelling measures within three years of becoming a party, including measures requiring minimum

\footnotetext{
${ }^{67}$ For example, United Nations Charter Article 103 could be used to argue that protections for human rights recognised in the agreement have hierarchy over conflicting rights.

68 Ricketson (n 31) 323.

69 ibid 150.

${ }^{70}$ See for example Australia - Certain Measures Concerning Trademarks and Other Plain Packaging Requirements Applicable to Tobacco Products and Packaging - Request for Consultations by Honduras, 10 April 2014, WT/DS435/1.

71 Wager and Watal (n 60) 159.

72 National Preventative Health Taskforce, Australia: Healthiest Country by 2020: Technical Report 2 Tobacco control in Australia: Making Smoking History Including Addendum for October 2008 to June 2009, (2009) 20.

${ }^{73}$ Andrew D. Mitchell and Tania Voon 'Introduction,' in Andrew D. Mitchell and Tania Voon (eds) The Global Tobacco Epidemic and the Law (Edward Elgar 2014) 1.

${ }^{74}$ Brigit Toebes and others, 'A Missing Voice: the Human Rights of Children to a Tobacco-Free Environment' (2018) 27 Tobacco Control, 3-5.

${ }^{75}$ WHO Framework Convention on Tobacco Control (opened for signature 21 May 2003, entered into force 27 February 2005) 2302 UNTS 166 (FCTC) preamble.
} 
sizing of graphic warnings about the negative health impacts of tobacco on tobacco packaging. The Guidelines to Article 11 were adopted by the COP 2008 to assist states to improve the effectiveness of measures for the packaging and labelling of tobacco related products in November $2008 .{ }^{76}$ Part of the guidelines recommend that parties adopt plain packaging measures. ${ }^{77}$ Contemporaneously, plain packaging was identified as a key priority in reducing rates of tobacco consumption in Australia in a 2008 discussion paper released by the Australian Government National Health Taskforce (the National Health Taskforce Paper). ${ }^{78}$

Subsequently, the Tobacco Plain Packaging Act 2011 (Cth), the Trade Marks (Plain Packaging) Act 2011 (Cth) and supporting regulations (plain packaging legislation) introduced broad requirements for the packaging of tobacco related products. Plain packaging legislation limits advertising. It limits use of trade marks to their traditional function of indicating source of origin and associated quality. ${ }^{79}$ The most relevant requirements to intellectual property are those that impact on the ability of owners of tobacco related trade marks to use their marks on packaging. ${ }^{80}$ Relevantly, the restrictions permit only use of word marks in prescribed size, font and colour in a designated position of the packet. ${ }^{81}$ Graphics or device marks cannot be used..$^{82}$ The Tobacco Plain Packaging Act 2011 articulates the primary policy concerns of Plain Packaging Legislation: the protection of public health and the implementation of the FCTC..$^{83}$

What was the impact of this on owners of tobacco related trade marks? Plain packaging legislation permits word marks to continue to be used by trade mark owners in a restricted way to denote the source of the product. ${ }^{84}$ The legislation also permits trade marks to stay on the register, even where they might be susceptible to non-use actions as a result of the legislation, which enabled trade mark owners to continue to exclude others from using the relevant registered marks. ${ }^{85}$ Tobacco companies have argued that these restrictions on the use of their trade marks have significant economic consequences. ${ }^{86}$ Tobacco related trade mark owners have claimed breach of their rights in domestic constitutional litigation, ${ }^{87}$ investor-state dispute litigation ${ }^{88}$ and the dispute settlement mechanisms of the WTO..$^{89}$

In the High Court of Australia, JT International and British American Tobacco unsuccessfully argued that Australian plain packaging legislation constituted acquisition of their trade mark rights by the government and this was inconsistent with constitutional requirements that the acquisition of

\footnotetext{
${ }^{76}$ At its third session in November 2008, the Conference of the Parties (COP) adopted guidelines for implementation of Article 11 of the WHO FCTC on 'Packaging and Labelling of Tobacco Products' (decision FCTC/COP3(10)) (Guidelines).

77 Guidelines, paragraph 46.

${ }^{78}$ National Preventative Health Taskforce, Australia: The Healthiest Country by 2020. Discussion paper. (Commonwealth of Australia 2008) (National Health Taskforce Paper) 23-24.

79 Tobacco Plain Packaging Act 2011 (Cth), s 21.

${ }^{80}$ Tobacco Plain Packaging Act 2011 (Cth), s 20.

${ }^{81}$ Tobacco Plain Packaging Act 2011 (Cth), s 21.

82 Tobacco Plain Packaging Act 2011 (Cth), s 21.

83 Tobacco Plain Packaging Act 2011 (Cth), s 3.

${ }^{84}$ Tobacco Plain Packaging Act 2011 (Cth), s 21.

${ }^{85}$ Explanatory Memorandum, Tobacco Plain Packaging Bill 2011 (Cth), 15.

${ }^{86}$ Notice of Arbitration, Australia/Hong King Investment Agreement for the Promotion and Protection of Investments (Philip Morris Asia Ltd. v. Austl.), UNCITRAL PCA Case. No. 2012-12, (Nov. 21, 2011) para 8.3.

87 JT International SA v Commonwealth of Australia; British American Tobacco Australasia Limited v The Commonwealth 250 CLR 1.

88 Philip Morris Asia Limited v. The Commonwealth of Australia, UNCITRAL, PCA Case No. 2012-12.

${ }^{89}$ Australia - Plain Packaging Measures.
} 
property be on just terms. ${ }^{90}$ The High Court found that the legislation did not acquire the applicants' intellectual property rights so the claim could not be established. ${ }^{91}$ Separately Philip Morris Asia commenced an international investment arbitration action against Australia. Philip Morris Asia argued that changes resulting from plain packaging legislation deprived them of the value of their investment as it was enacted subsequent to their acquisition of intellectual property rights to tobacco. ${ }^{92}$ This was alleged to be inconsistent with Australia-Hong Kong Bilateral Investment Treaty. ${ }^{93}$ However, it was found that these rights had been deliberately acquired so as to exploit the investor state dispute mechanism. ${ }^{94}$ The action ended in interlocutory proceedings that determined the bringing of the claim in these circumstances constituted an abuse of right under international law. ${ }^{95}$

The WTO Disputes were brought against Australia by Cuba, the Dominican Republic, Honduras and Indonesia pursuant to the DSU. The Ukraine also initiated but then suspended a dispute, which has subsequently lapsed. ${ }^{96}$ The complaints asserted that Australia's plain packaging legislation breached Article 20 of TRIPS as it contained special requirements that unjustifiably encumbered the use of tobacco related trade marks in the course of trade. ${ }^{97} \mathrm{~A}$ range of other complaints were also made asserting breaches of TRIPS and the TBT. Australia justified the impugned provisions citing domestic public health objectives and compliance with the FCTC. ${ }^{98}$ Importantly, tobacco companies with interests in the promotion and sale of tobacco have openly acknowledged that they are funding the WTO actions against Australia. ${ }^{99}$ This funding relationship is complex in light of human rights obligations for states to perform human rights scrutiny of corporate entities operating in their territories. ${ }^{100}$ Permitting tobacco companies to fund actions that assert rights to market products that are known to be harmful to health can engage human rights obligations to protect individuals from potential infringements of the right to health that are discussed in the next section.

\subsection{What human rights are engaged by the WTO Dispute?}

Australian plain packaging legislation engages a range of human rights considerations but the disputes have not focused on relevant human rights obligations. The emphasis on discussion has been on health and although the right to health is clearly implicated, the discourse has focused on

\footnotetext{
${ }^{90}$ JT International SA v Commonwealth of Australia; British American Tobacco Australasia Limited v The Commonwealth 250 CLR 1.

${ }^{91}$ JT International SA v Commonwealth of Australia; British American Tobacco Australasia Limited v The Commonwealth 250 CLR 1, 34-5 (French CJ).

92 Philip Morris Asia Ltd v Australia, PCA Case No 2012-12, UNCITRAL, Award on Jurisdiction and Admissibility (17 December 2015) (8 May2018) para 48.

${ }^{93}$ Notice of Arbitration, Australia/Hong King Investment Agreement for the Promotion and Protection of Investments (Philip Morris Asia Ltd. v. Austl.), UNCITRAL PCA Case. No. 2012-12, (Nov. 21, 2011) para 8.3. 94 Philip Morris Asia Ltd v Australia, PCA Case No 2012-12, UNCITRAL, Award on Jurisdiction and Admissibility (17 December 2015).

95 ibid [586]-[588].

${ }^{96}$ Australia - Plain Packaging Measures [1.51]-[1.54].

${ }^{97}$ See for example Australia - Certain Measures Concerning Trademarks and Other Plain Packaging Requirements Applicable to Tobacco Products and Packaging - Request for consultations by Honduras, 10 April 2014, WT/DS435/1.

${ }^{98}$ Australian Department of Foreign Affairs and Trade $(\mathrm{n} 9)$.

${ }^{99}$ Stephanie Nebehay, 'Australia says Big Tobacco aiding WTO challengers' (23 May 2012) http://www.reuters.com/article/trade-tobacco-idUSL5E8GMHBW20120522 (accessed 8 May 2018).

100 General Comment 24 explicitly requires parties to ICESCR to consider measures such as restricting marketing tobacco products to protect public health: Committee on Economic, Social and Cultural Rights, General Comment No 24: State Obligations under the International Covenant on Economic, Social and Cultural Rights in the Context of Business Activities, UN ESCOR, 61 $1^{\text {st }}$ sess, UN Doc E/C.12/GC/24 (23 June 2017) ('General Comment 24') [19].
} 
public health considerations. ${ }^{101}$ Commercial speech is a form of expression and restrictions on trade marks have been argued to be a restriction on freedom of expression. ${ }^{102}$ Arguably, moral and material rights of creators of certain tobacco-related trade marks can be protected pursuant to ICESCR Article 15(1)(c). Human rights to property not restricted to scientific, literary and artistic productions and rights to development could also be relevant to the disputes. A right to development entitles 'every human person and all peoples.. to participate in, contribute to, and enjoy economic, social, cultural and political development. ${ }^{103}$ Human rights obligations to property and development are harder to identify as relevant to interpretation of TRIPS obligations in the WTO Disputes as they are less clearly defined in international law.

\subsubsection{Right to Health}

Australia is bound by the ICESCR and has acknowledged the relevance of the human right to the highest attainable standard of health in explanatory material surrounding plain packaging legislation. ${ }^{104}$ Compliance with the FCTC is an objective of the legislation. ${ }^{105}$ The FCTC recognises both the human right to health and public health imperatives. ${ }^{106}$ There is debate about the extent to which the FCTC Guidelines that require States to implement plain packaging constitute binding obligations in international law, ${ }^{107}$ yet the requirement of ICESCR that States progressively realise the human right to health for individuals is clear. ${ }^{108}$ CESCR's General Comment 14 interpreting the right to health identifies tobacco-related measures as relevant to the right to health. ${ }^{109} \mathrm{~A}$ key relevant obligation engaged by plain packaging legislation is Australia's obligation to protect the right to health by taking 'all necessary measures to safeguard persons within their jurisdiction from infringements of the right to health by third parties. ${ }^{110}$ CESCR includes the failure of states to regulate the activities of corporations that will violate the right to health of others and the failure to protect consumers and workers from activities that are detrimental to health, including marketing and consumption of tobacco. ${ }^{111}$ There is well documented evidence of intentional failure to disclose negative health impacts of tobacco by tobacco companies, which engages additional obligations for States to protect individuals. ${ }^{112}$ Australia has attempted to address this protection obligation through the plain packaging legislation.

\footnotetext{
${ }^{101}$ See generally Voon, Mitchell and Liberman (n 50).

102 Mariette Brennan, Canada's Next Step in Tobacco Control Laws: Is Plain Packaging Legislation a Viable Proposal (2013) 51 Alberta Law Review 23.

103 United Nations Declaration on the Right to Development, UN GA Res 41/128, UN Doc 41/128 (4 December 1986) art 1.1.

${ }^{104}$ Explanatory Statement 'Tobacco Plain Packaging: Amendment Regulation 2012 (No 1)' (5LI, No 29 of 2012 ).

105 Plain Packaging Act 2011 (Cth), s 3.

${ }^{106}$ FCTC preamble.

${ }^{107}$ Chang-fa Lo, 'Guidelines and Protocols under the Framework Convention,' in Andrew D. Mitchell and Tania Voon (eds), The Global Tobacco Epidemic and the Law (Edward Elgar, 2014) 32-45; Jonathan Liberman, 'The Power of the WHO FCTC: Understanding Its Legal Status and Weight' in Andrew D Mitchell and Tania Voon (eds), The Global Tobacco Epidemic and the Law (Edward Elgar, 2014) 48-60.

108 ICESCR art 12; United Nations Committee on Economic, Social and Cultural Rights ('CESCR'), General Comment No. 14: The Right to the Highest Attainable Standard of Health (Art 12 of the Covenant), 11 August 2000, E/C.12/2000/4 (General Comment 14).

109 General Comment 14, [51].

110 Ibid.

111 Ibid.

112 Melissa E. Crow, 'Smokescreens and State Responsibility: Using Human Rights Strategies to Promote Global Tobacco Control' (2005) 29 Yale Journal of International Law 209, 211; Carolyn Dresler and Stephen P. Marks, 'The Emerging Human Right to Tobacco Control' (2006) 28(3) Human Rights Quarterly 599, 633, 644.
} 
A key priority of plain packaging legislation is to reduce the attractiveness and appeal of tobacco products to young people. ${ }^{113}$ This also corresponds to Australia's obligations pursuant to the Convention on the Rights of the Child to protect the rights of children to 'the enjoyment of the highest attainable standard of health' ${ }^{114}$ and to ensure that the child has 'access to information and material from a diversity of national and international source, especially those aimed the promotion of his or her social, spiritual and moral well-being and physical and mental health. ${ }^{115}$ General Comment 4 of the Committee of the Rights of the Child (COMRC) on Adolescent Health and Development interprets this obligation to protect adolescents from information that is harmful to their health and development. ${ }^{116}$ States should 'regulate or prohibit information and marketing of... tobacco, particularly when it targets children and adolescents.' ${ }^{117}$ This obligation is directly relevant to the restrictions on marketing required by plain packaging legislation. These restrictions are supported by scientific evidence regarding adolescents and plain packaging. ${ }^{118}$

The effectiveness of States measures to achieve progressive realisation of its human right to health obligations is a relevant consideration to assessing compliance with those obligations. In 2008, the National Health Taskforce Report identified that decline rates of tobacco consumption in Australia were 'flattening out.' ${ }^{119}$ Plain packaging legislation formed part of the policy that responded to concerns of the negative health impacts of continuing tobacco consumption. The key health claims of plain packaging legislation are that it will:

- 'reduce the attractiveness and appeal of tobacco products to consumers, particularly young people;

- increase the noticeability and effectiveness of mandated health warnings;

- reduce the ability of the tobacco product packaging to mislead consumers about the harms of smoking; and

- through the achievement of these objectives in the long term, as part of a comprehensive suite of tobacco control measures, contribute to efforts to reduce smoking rates. ${ }^{120}$

\footnotetext{
113 Tobacco Plain Packaging Bill 2011, Explanatory Memorandum.

${ }^{114}$ Convention on the Rights of the Child (opened for signature 20 November 1989, entered into force 2 September 1990) 1577 UNTS 3 (CRC) art 24.

115 CRC art 17.

${ }^{116}$ UN Committee on the Rights of the Child, General Comment No. 4: Adolescent Health and Development in the Context of the Convention on the Rights of the Child [6] [21-2] UN Doc.: CRC/GC/2003/4

http://www.ohchr.org/Documents/Issues/Women/WRGS/Health/GC4.Pdf

117 Ibid [21].

118 Toebes and others also identify packaging of cigarettes and misleading advertising on cigarettes as important issues for governments to address to protect children's rights: Toebes and others ( $n$ 74) 4. Sally Dunlop and others 'Australia's Plain Tobacco Packs: Anticipated and Actual Responses among Adolescents and Young Adults 2010-2013' (2016) Tobacco Control 0:1-10. See also Richard Edwards and others 'Impact of Removing Point-Of-Sale Tobacco Displays: Data from a New Zealand Youth Survey' (2016) Tobacco Control 0:1-7.

119 National Health Taskforce Paper (n 78) 21.

120 Tobacco Plain Packaging Bill 2011, Explanatory Memorandum, 1.
} 
The substantial scientific basis for these claims was set out in a technical report accompanying the National Health Taskforce Report. ${ }^{121}$ Additional scientific evidence supported the policy. ${ }^{122}$ Competing reports questioned the effectiveness of the proposed measure. ${ }^{123}$

Following the introduction of plain packaging legislation, early analysis indicated the success of the measure in reducing the appeal of tobacco packaging for adolescents, ${ }^{124}$ influencing decisions to cease smoking in adult smokers ${ }^{125}$ and causing smokers to conceal their packs. ${ }^{126}$ Although the benefits of plain packaging legislation in effecting a decline in smoking are expected to be long term benefits, ${ }^{127}$ further evidence establishes the short-term effectiveness of the measure. ${ }^{128}$ Multiple tobacco control measures in place in Australia contribute to smoking rates ${ }^{129}$ however the 2016 Post Implementation Review concluded that all of the major datasets examined demonstrated sustained drops in national smoking prevalence in Australia. ${ }^{130}$ This reduction was expected to have significant long term impact on public health outcomes and suggested that the legislation was fulfilling its

${ }^{121}$ See Janne Scheffels, 'A Difference That Makes a Difference: Young Adult Smokers' Accounts of Cigarette Brands and Package Design' (2008) 17(2) Tobacco Control 118; M Wakefield et al, 'The Cigarette Pack as Image: New Evidence from Tobacco Industry Documents' (2002) 11(Suppl 1) Tobacco Control i73; Becky Freeman, Simon Chapman and Matthew Rimmer, 'The Case for Plain Packaging of Tobacco Products' (2008) 103(4) Addiction 580; MA Wakefield, D Germain and SJ Durkin, 'How Does Increasingly Plainer Cigarette Packaging Influence Adult Smokers' Perceptions about Brand Image? An Experimental Study' (2008) 17(6) Tobacco Control 416; P Beede and R Lawson, 'The Effect of Plain Packages on the Perception of Cigarette Health Warnings' (1992) 106(4) Public Health 315; ME Goldberg et al, 'The Effect of Plain Packaging on Response to Health Warnings.' (1999) 89(9) American Journal of Public Health 1434; E Strahan and others, 'Enhancing the Effectiveness of Tobacco Package Warning Labels: A Social Psychological Perspective' (2002) 11(3) Tobacco Control 183; M Wakefield and T Letcher, 'My Pack Is Cuter than Your Pack' (2002) 11(2) Tobacco Control 154; Morgan Stanley Research Europe, Tobacco: Late to the Party (Morgan Stanley Research, 2007).

${ }^{122}$ Quit Victoria, Cancer Council Victoria, Plain Packaging of Tobacco Products: A Review of the Evidence (May 2011).

${ }^{123}$ Philip Johnson 'Trademarks Without a Brand: The Proposals on" Plain Packaging" of Tobacco Products.'(2012) 34(7) European Intellectual Property Review 468-469.; British American Tobacco, British American Tobacco Australia Submission on the Tobacco Plain Packaging Bill 2011, 6 June 2011, http://www.ipwatch.org/weblog/wp-content/uploads/2011/06/BATA-Tobacco-Plain-Packaging-Bill-Submission.pdf accessed 9 May 2018); Philip Morris, Commoditising tobacco products through plain packaging will harm public health, violate treaties, and does not meet the test of "evidence-based policy": Submission by Philip Morris Limited on the Tobacco Plain Packaging Bill Exposure Draft, June 2011,

http://webarchive.nla.gov.au/gov/20130329051831/http://www.yourhealth.gov.au/internet/yourhealth/publi shing.nsf/Content/Phillip-Morris-Limited Phillip-Morris-Limited-2 accessed 9 May 2018.

${ }^{124}$ Victoria White, Tahlia Williams and Melanie Wakefield 'Has the Introduction of Plain Packaging with Larger Graphic Health Warnings Changed Adolescents' Perceptions of Cigarette Packs and Brands?' (2015) 24(Suppl 2) Tobacco Control pp ii42-ii49.

${ }^{125}$ Melanie Wakefield and others 'Introduction Effects of the Australian Plain Packaging Policy on Adult Smokers: A Cross-Sectional Study' (2013) 3(7) BMJ Open e003175.

${ }^{126}$ Meghan Zacher and others, 'Personal Pack Display and Active Smoking at Outdoor Café Strips: Assessing the Impact of Plain Packaging 1 Year Post Implementation' (2015) 24 Tobacco Control 94-97.

${ }^{127}$ Tasneem Chipty, Study of the Impact of the Tobacco Plain Packaging Measure on Smoking Prevalence in Australia (2016)

http://www.health.gov.au/internet/main/publishing.nsf/content/491CE0444F7B0A76CA257FBE00195BF3/\$Fil e/PIR\%20of\%20Tobacco\%20Plain\%20Packaging\%20-\%20with\%20Addendum.pdf accessed 9 May 2018 (PostImplementation Review).

${ }^{128}$ ibid, Appendix A, para. 6.

${ }^{129}$ Australian Department of Foreign Affairs and Trade (n 9) [150].

${ }^{130}$ Davidson and Da Silva contest some of these. Sinclair Davidson and Ashton de Silva, 'Did Recent Tobacco Reforms Change the Cigarette Market?' (2018) 37(1) Economic Papers: A Journal of Applied Economics and Policy 55, 69-70. 
aims. ${ }^{131}$ The Post Implementation Review analysis did not assess whether alternative measures, other than not introducing the legislative measures at all, would have been more effective or equally effective. ${ }^{132}$ There have been criticisms of these findings which partly reflect the fact that tobacco plain packaging is designed to be a long term measure. ${ }^{133}$ At this stage it is difficult to definitively assess the effectiveness of plain packaging legislation in meeting Australia's progressive realisation of the right to health but, if this can be established, repeal of the legislation could constitute a retrogression in Australia progressively realising its human right to health obligations. ${ }^{134}$

\subsubsection{Freedom of Expression}

Arguably the freedom of expression rights of tobacco owners are restricted by plain packaging legislation as owners cannot use the marks on packaging as a form of expression. ${ }^{135}$ The human right to freedom of expression enshrined in Article 19 of the International Covenant on Civil and Political Rights (ICCPR), ${ }^{136}$ as interpreted by the Human Rights Committee in General Comment 34 states that freedom of expression may include commercial advertising. ${ }^{137}$ However, the restrictions on the use of trade marks imposed by plain packaging legislation may be permissible restrictions. ICCPR Article 19(3) permits restrictions that are provided in law and necessary for respect of the rights or reputations of others, for the protection of national security, public order, or public health or morals. ${ }^{138}$ The Human Rights Committee confirms ${ }^{139}$ that restrictions other than those specified in paragraph 3 are not allowed 'even if such grounds would justify restrictions to other rights protected in the Covenant. ${ }^{140}$ There needs to be a direct relationship between the specified justification and the application of the restriction. ${ }^{141}$

The content of Australian plain packaging legislation also suggests that it is necessary for the protection of public health. ${ }^{142}$ This is one of the permissible restrictions set out in ICCPR Article 19(3). However, a restriction does not meet the test of necessity 'if the protection could be achieved in other ways that do not restrict freedom of expression. ${ }^{143}$ General Comment 34 does not provide further specific guidance on public health. General Comment 34 interprets the rights referred to in Article 19(3) to include human rights, so any restriction on freedom of expression posed by plain packaging legislation can be justified as necessary to achieve realisation of the human right to health. ${ }^{144}$ The objective of protecting the human right to health has been identified in explanatory materials for plain packaging legislation and its relevance has been explained above. ${ }^{145}$ The Human Rights Committee adopts earlier statements that restrictive measures should not be overbroad and

\footnotetext{
${ }^{131}$ Chipty (n 127) 20.

132 ibid.

133 Davidson and Da Silva, n 118.

134 General Comment 14 [48].

${ }^{135}$ Explanatory Statement, Tobacco Plain Packaging Amendment Regulation 2012 (No. 1) (Cth) 9-13. Brennan considers whether plain packaging legislation would be consistent with the broader freedom of expression protections found in the Canadian Charter: Mariette Brennan, Canada's Next Step in Tobacco Control Laws: Is Plain Packaging Legislation a Viable Proposal (2013) 51 Alberta Law Review 23, 35-48.

${ }^{136}$ International Covenant on Civil and Political Rights, opened for signature 16 December 1966, 999 UNTS 171 (entered into force 23 March 1976) (ICCPR)

137 Human Rights Committee, General Comment No. 34 (2011) Article 19: Freedoms of Opinion and Expression 138 ICCPR art 19(3).

139 United Nations Human Rights Committee, General Comment No 34 - Article 19: Freedoms of Opinion and Expression, $102^{\text {nd }}$ sess, UN Doc CCPR/C/GC/34 (12 September 2011) (General Comment 34).

140 General Comment 34, [22].

141 ibid [22].

142 Tobacco Plain Packaging Act 2011 (Cth), s 3.

143 General Comment 34, [33].

144 ibid.

${ }^{145}$ Explanatory Statement, Tobacco Plain Packaging: Amendment Regulation 2012 (No 1) (5LI, No 29 of 2012 ).
} 
should be consistent with the principle of proportionality which 'must also take account of the form of expression at issue as well as the means of its dissemination. ${ }^{146}$ Policy documents supporting Australian plain packaging legislation, including the National Health Taskforce Report and supporting documentation set out 'in specific and individualized fashion the precise nature of the threat, and the necessity and proportionality of the specific action taken. ${ }^{147}$ If plain packaging legislation constitutes a restriction on freedom of expression, it can be concluded that the restriction is provided by law and does not appear to be discriminatory to any particular group so it should not be a basis to modify or restrict the legislation.

\subsubsection{Right to Benefit from Science and Culture}

Article 15(1)(c) confers limited human rights protection for creators of literary, artistic and scientific productions. Where trade marks constitute literary or artistic productions, ICESCR Article 15(1)(c) could confer moral and material rights on the authors of those trade marks. ${ }^{148}$ Tobacco related device marks and composite marks can constitute artistic productions so creators of trade marks could argue that plain packaging legislation impacts on their moral and material rights. However, it is not clear that the rights protected by Article 15(1)(c) are directly restricted by plain packaging legislation. There is no pre-existing practice of providing moral rights of attribution trade mark creators. ${ }^{149}$ The human right provided in Article 15(1)(c) does not provide for ongoing renumeration, ${ }^{150}$ so it may be assumed that creators of trade marks have already been compensated and their material interest in 15(1)(c) is not impaired. The legislation does not appear to be the direct cause of the loss of material or moral rights so in the present assessment of interrelated rights it should not be the basis to restrict operation of the legislation to realise the relevant right to health objectives. ${ }^{151}$

\subsubsection{Human rights to property and development}

Human rights to property and development have been recognised as relevant to the WTO disputes. ${ }^{152}$ Neither right is enshrined in binding international human rights agreements. Although development concerns are clearly relevant to the object and purpose of TRIPS, the status of the human right to development also remains unclear. ${ }^{153}$ It is arguable that the restrictions imposed by Plain Packaging Legislation impair the economic development of countries who depend on exports of tobacco related products to Australia for income. ${ }^{154}$ Importantly economic development is itself

\footnotetext{
146 General Comment 34, [34].

147 General Comment 34, [35].

${ }^{148} \mathrm{Cf} Y u(\mathrm{n} 38)$ 85-95.

${ }^{149}$ See generally Trade Marks Act 1995 (Cth).

${ }^{150}$ Committee on Economic, Social and Cultural Rights, The Right of Everyone to Benefit from the Protection of the Moral and Material Interests Resulting from Any Scientific, Literary or Artistic Production of which He or She is the Author (article 15, paragraph 1 (c), of the Covenant), General Comment No. 17 (2005), U.N. ESCOR, 35th Sess., U.N. Doc. E/C.12/GC/17 (2006) [16].

${ }^{151}$ Helfer and Austin argue that when we consider potential conflicts between human rights and intellectual property, it is necessary to recognise if the intellectual property legislation that is alleged to be in conflict with the relevant human rights is in fact the reason for the restriction of the rights: Helfer and Austin (n 6) 520. 152 Brigit Toebes, 'Human Rights and Public Health: Towards a Balanced Relationship' (2015) 19(4) The International Journal of Human Rights 488, 495; Albert Alemanno and Enrico Bonadio 'Do You Mind My Smoking? Plain Packaging of Cigarettes Under the TRIPS Agreement' (2011) 10 The John Marshall Review of Intellectual Property Law 449.

153 TRIPS Preamble; Uvin questions the status of the right to development: Peter Uvin, 'From The Right To Development To The Rights-Based Approach: How “Human Rights" Entered Development' (2007) 17(4/5) Development in Practice 597.

${ }^{154}$ Brigit Toebes (n 152) 495. In the WTO Disputes, Cuba argued that plain packaging measures were detrimental to its economic development because of the importance of its tobacco industries: Australia - Plain Packaging Measures, Annex B-3, B-62.
} 
impacted by the burden of tobacco related disease. ${ }^{155}$ Health concerns related to tobacco consumption are also problematic for countries that are producers of tobacco. ${ }^{156}$ Accordingly, Objective 3.a of the United Nations Sustainable Development Goals is to '[s]trengthen the implementation of the World Health Organization Framework Convention on Tobacco Control in all countries, as appropriate. ${ }^{157}$

Although property concerns are also clearly relevant to disputes concerning plain packaging legislation, ${ }^{158}$ the human right to property has been narrowly interpreted in jurisdictions where protection exists. ${ }^{159}$ States are generally given a wide margin of appreciation in European jurisprudence considering whether there has been interference with property rights. ${ }^{160}$ Relevant considerations are whether a fair balance has been struck between the interests of the community and those of the applicant, placing on the applicant an individual and excessive burden. ${ }^{161}$ The right to health concerns outlined above suggest that plain packaging legislation supports the interests of the community and this would be important to a human right to property assessment. Even though rights to property and development may be engaged by plain packaging legislation, the uncertain nature of both rights means that it would be difficult to argue that either right should be considered in the WTO disputes. ${ }^{162}$

\subsection{Relevance of human rights engaged}

Several human rights considerations are engaged by plain packaging legislation. The analysis suggests that the human rights claim that is most relevant to the WTO disputes is the right to health. The following section will focus on the right to health and the way in which human rights are relevant to the interpretation of TRIPS in the WTO Disputes even though they have not been the focus of argument.

\section{HOW DOES THE OBJECT AND PURPOSE OF TRIPS PERMIT CONSIDERATIONS OF HUMAN RIGHTS IN THE WTO DISPUTES?}

\subsection{Interpreting the term 'unjustifiably' in the WTO Disputes}

In the WTO Disputes, the complainants asserted that plain packaging constituted multiple breaches of TRIPS and the separate WTO Agreement on Technical Barriers to Trade. ${ }^{163}$ Article 20 of TRIPS requires that ' $[t]$ he use of a trademark in the course of trade shall not be unjustifiably encumbered by special requirements.' Plain packaging legislation only permits use of a trade mark on packaging in a proscribed form, in certain locations on the packaging, in combination with health warnings,

\footnotetext{
155 Oscar A. Cabrera and Lawrence O. Gostin 'Human rights and the Framework Convention on Tobacco Control: Mutually Reinforcing Systems' (2011) 7(3) International Journal of Law in Context 285, 286.

156 Oscar A Cabrera and Juan Carballo 'Tobacco Control in Latin America' in Mitchell and Voon, n 63, 236.

157 United Nations General Assembly (2015). Transforming Our World: The 2030 Agenda for Sustainable Development, A/RES/70/1. <http://www.refworld.org/docid/57b6e3e44.html> accessed 12 May 2018. 158 JT International SA v Commonwealth of Australia; British American Tobacco Australasia Limited $v$ The Commonwealth 250 CLR 1.

159 Marco Ricolfi 'Trademarks and Human Rights' in Paul Torremans (ed), Intellectual Property Law and Human Rights (Kluwer Law International 2015).

${ }^{160}$ Anheuser-Busch Inc v Portugal, Merits, App no 73049/01, (2007) 44 EHRR 42, IHRL 3436 (ECHR 2007), 11th January 2007, European Court of Human Rights (Anheuser-Busch v Portugal); Helfer (n 20) 3.

${ }^{161}$ See, for example, the reasoning in Balan v Moldova (no 19247/03) ECHR, 29 April 2008.

162 Neither is a clearly defined human right in customary international law or protected by a binding international agreement which lessens the likelihood of their interpretive relevance. See Uvin (n 153); Yu (n 38) 85-95.

163 See generally Australia - Plain Packaging Measures.
} 
graphic photographs and the Quitline mark. ${ }^{164}$ The Panel found that plain packaging legislation constitutes special requirements that are an unjustified encumbrance on the use of the relevant trade marks in the course of trade. ${ }^{165}$ This section will focus on the Article 20 arguments concerning justifiability of plain packaging measures. These provide scope for interpretation of the term 'unjustifiably' using VCLT interpretative tools. As set out above, the VCLT provides guidelines to the WTO Dispute Settlement Body regarding interpretation. The nature of the encumbrance that must be justified is subject to interpretation. ${ }^{166}$ In relation to TRIPS, both the preamble and articles 7 and 8 are relevant provisions to the object and purpose of the treaty, which will guide interpretation of Article $20 .{ }^{167}$ This chapter sets out the approach taken by the Panel and analyses the relevance of human rights to interpretation of the term 'unjustifiably' in Article 20 in the context of the WTO Disputes, applying the interpretive principles found in Article 31 of the Vienna Convention on the Law of Treaties (VCLT). This section will argue that human rights can be relevant to the interpretation of 'unjustifiably' in determining whether plain packaging legislation constituted special requirements that unjustifiably encumbered the use of tobacco related trade marks in the course of trade.

The Panel approached the interpretative exercise by ascertaining the ordinary meaning of 'unjustifiably' then using other provisions of TRIPS to identify the types of reasons relevant to justifiability. ${ }^{168} \mathrm{~A}$ broad range of potential meanings for 'unjustifiably' suggests that further interpretative tools provided by the VCLT are relevant in interpreting its meaning. ${ }^{169}$ Ruse-Khan argues that it is most important to refer to balancing provisions when the relevant articles contain terms that are not explicit. ${ }^{170} \mathrm{He}$ identifies a number of 'broad and open legal concepts' within TRIPS, including normal exploitation, legitimate interests, (un) reasonableness, necessity and ordre public. ${ }^{171}$ As discussed in section 3.1 of this chapter, VCLT Article 31 requires interpretation 'in good faith in accordance with the ordinary meaning to be given to the terms of the treaty in their context and in the light of its object and purpose.' The context of a treaty term or provision includes the text, the preamble, annexes and agreements made in connection with conclusion of the treaty. ${ }^{172}$

The Panel determined that the term unjustifiably referenced 'the ability to provide a "justification" or "good reason" for the relevant action or situation that is reasonable in the sense that it provides sufficient support for that action or situation. ${ }^{173}$ It then recognised the relevance of the object and purpose of TRIPS to understanding what reasons could be relevant to justifiability and considered

\footnotetext{
${ }^{164}$ Andrew D Mitchell, 'Australia's Move to the Plain Packaging of Cigarettes and Its WTO Compatibility' (2010) 5 Asian Journal of WTO and International Health Law and Policy 405, 412; Daniel Gervais, 'Plain packaging and the TRIPS Agreement: A Response to Professors Davison, Mitchell and Voon' (2013) 23 Australian Intellectual Property Journal 96, 103. Cf Mark Davison 'The Legitimacy of Plain Packaging under International Intellectual Property Law,' in Voon, Mitchell and Liberman (n 50) 94-96.

165 Australia - Plain Packaging Measures [7.2292]

${ }^{166}$ Frankel and Gervais (n 57) 1172-4.

167 ibid, 1167-1168.

${ }^{168}$ Australia - Plain Packaging Measures [7.2393]-[7.2431].

${ }^{169}$ Frankel and Gervais have argued that other WTO case law suggests standards ranging from having a rational relationship to the measure to having a substantial or firm evidence base to a near certain correlation: ibid, 1204-6.

${ }^{170}$ Henning Grosse Ruse-Khan, 'Proportionality and Balancing within the Objectives for Intellectual Property Protection' in Paul L. C. Torremans (ed), Intellectual Property and Human Rights (Kluwer Law International, 2008), 162-3; this is similar to Land's argument that standards provision and textual silence are types of flexibility mechanisms, Molly Land "Rebalancing TRIPS" (2011-2012) 33 Michigan Journal of International Law 433, 438-442.

${ }^{171}$ Henning Grosse Ruse-Khan, ibid, 162-3.

172 VCLT art 31(2).

${ }^{173}$ Australia - Plain Packaging Measures [7.2395].
} 
the preamble, Article 7 and Article 8 of TRIPS. ${ }^{174}$ The preamble notes the importance of protection and enforcement of intellectual property but also recognises public policy objectives underlying domestic systems of intellectual property protection that can be relevant to the object and purpose of the agreement. ${ }^{175}$ As part of its analysis, the Panel identified the Doha Declaration on Public Health as a subsequent agreement relevant to interpretation of TRIPS. ${ }^{176}$ The Doha Declaration identifies the significance of Articles 7 and 8 to understanding the object and purpose of TRIPS and the Panel was guided by this in its assessment that societal interests were relevant to justifiableness. ${ }^{177}$ The Panel characterised Article 20 as reflecting an intended balance by drafters of the TRIPS Agreement 'between the existence of a legitimate interest of trademark owners in using their trademarks in the marketplace, and the right of WTO Members to adopt measures for the protection of certain societal interests that may adversely affect such use. ${ }^{178}$ In interpreting the unjustifiableness of the encumbrance posed by plain packaging legislation, the content of Articles 7 and 8 influenced the Panel's identification of public health considerations as relevant to societal interests. ${ }^{179}$

The Panel also considered the relationship between justifiability and necessity in its assessment of the Article 20 claims. ${ }^{180}$ Some complainants argued that (particularly in relation to health) 'unjustifiably' can be interpreted to require measures to be necessary, a term that has been interpreted in relation to other WTO Agreements. ${ }^{181}$ The Panel found that interpretation of the term 'unjustifiably' was specific to the TRIPS Agreement and a separate term to 'unnecessarily' was deliberately chosen. ${ }^{182}$ The use of the term 'necessary' in Article 8.1 may have influenced the emphasis given to Articles 7 and 8 in the Australian arguments. ${ }^{183}$ The long term, integrated nature of the public health measures in plain packaging legislation mean that it would be difficult to empirically compare the measure to other reasonably-available alternative measures and this may make any assessments of adequacy of the measure by the dispute settlement bodies more complex. ${ }^{184}$ Prior to the WTO Disputes there had been limited prior interpretation of Article 8 to clarify whether use of it in interpretation of Article 20 would engage a strict necessity test. ${ }^{185}$ Australia provide extensive evidence of the public health justification for plain packaging ${ }^{186}$ but it did not characterise this as a necessary public health measure pursuant to TRIPS Article 8.1. ${ }^{187}$ Instead it argued that Article 8 expressly acknowledges 'the broad scope that Members retain under the TRIPS Agreement to adopt laws and regulations for public policy purposes. ${ }^{188}$ Instead of explicitly linking this to object and purpose, Australia emphasised that the core object and purpose

\footnotetext{
${ }^{174}$ Australia - Plain Packaging Measures [7.2398]-[7.2402]

175 TRIPS, preamble.

${ }^{176}$ Australia - Plain Packaging Measures [7.2409]-[7.2410]

177 Australia - Plain Packaging Measures [7.2399]-[7.2402]

178 Australia - Plain Packaging Measures [7.2429].

${ }^{179}$ Australia - Plain Packaging Measures [7.2406], [7.2588]. Ruse-Khan notes that the 'unjustifiability' requirement in Article 20 allows the consideration of competing policies and interests, such as public health: Henning Grosse Ruse-Khan (n 33) 344. Frankel recognises 'health' as an open-textured term: Frankel (n 45) 421.

${ }^{180}$ Australia - Plain Packaging Measures [7.2413]-[7.2431]

${ }^{181}$ Australia - Plain Packaging Measures [7.2299], [7.2322], [7.2309], [7.2326]

${ }^{182}$ Australia - Plain Packaging Measures [7.2419]-[7.2422]

${ }^{183}$ Australia - Plain Packaging Measures [7.2327]-[7.2348]

${ }^{184}$ Frankel and Gervais identify the likelihood that adequacy could be considered: Frankel and Gervais ( $n$ 57) 1204.

185 Ibid [88]; Daniel Gervais The TRIPS Agreement: Drafting History and Analysis (4 ${ }^{\text {th }}$ Edition, Sweet and Maxwell 2008) 240-241.

${ }^{186}$ See Panel's summary: Australia - Plain Packaging Measures [7.2586]-[7.2589]

${ }^{187}$ Australia - Plain Packaging Measures [7,2348]

${ }^{188}$ Australia - Plain Packaging Measures [7.2346]
} 
of TRIPS is 'to ensure that all WTO Members provide a minimum level of exclusive rights to owners of IP.' ${ }^{\prime 189}$ Linking public policy considerations more explicitly to object and purpose could strengthen the interpretative weight given to these public policy considerations. This may permit WTO members to address the fragmentation between WTO law and other obligations identified in Section 2.1 of this chapter, using the example of human rights. The following analysis argues that right to health obligations could also be relevant for interpretation of unjustifiably.

A human rights-focused analysis contrasts to the emphasis on public health in the arguments engaging Article 20 in the WTO Disputes. Although the Panel recognised the justifiability of the legislation, it did not consider the human rights justifications. ${ }^{190}$ This is consistent with the absence of emphasis on human rights by all of the parties in argument, including the failure of Australia to rely on human rights to support Plain Packaging legislation. ${ }^{191}$ However, the reference to health objectives in plain packaging legislation and the recognition of the role of the legislation in furthering the right to health in explanatory legislative materials indicate that protection of the human right to health is a relevant underlying policy objective of the legislation. ${ }^{192}$ The decision presents opportunities for future recognition of human rights in TRIPS disputes. In interpreting the unjustifiableness of the encumbrance posed by plain packaging legislation, the Panel considered the object and purpose of TRIPS discernible from the Preamble, Articles 7 and $8 .{ }^{193}$ Taking this approach, it recognised the relevance of societal interests including public heath, to assessments of unjustifiableness. ${ }^{194}$ In future disputes societal interests could be interpreted to directly overlap with the protection of human rights that can be linked to the object and purpose of TRIPS such as the right to health. ${ }^{195}$ This interpretative approach could be relevant to other 'open textured' terms in TRIPS ${ }^{196}$ and reduce the impact of fragmentation between different fields of law.

The balance of rights and obligations referenced in Article 7 of TRIPS can be linked to the underlying public policy objectives of the Australian system of intellectual property protection which include compliance with other international obligations. ${ }^{197}$ This article has set out provisions of ICESCR and the Convention on the Rights of the Child that can be interpreted to justify the introduction of plain packaging in Australia. Although there continues to be dispute about the extent to which the FCTC Guidelines require the implementation of plain packaging, in the WTO Disputes engaging TRIPS Article 20, Australia's FCTC obligations were identified by the Panel as relevant to its justification for implementing plain packaging legislation. ${ }^{198}$. The objective of protecting health by reducing tobacco consumption is not only relevant to understanding underlying policy objectives and a balance of rights and obligations but is also relevant to social and economic welfare, which is an objective identified in Article 7. Further, in interpreting whether restricting the use of trade marks on tobacco packaging 'unjustifiably' encumbers use of a mark, Australia's obligation to protect the right to health is relevant to a balance of rights and obligations, consistent with the principle articulated Article 7.

\footnotetext{
${ }^{189}$ Australia - Plain Packaging Measures [7.2344]

${ }^{190}$ Australia - Plain Packaging Measures [7.2598].

${ }^{191}$ Australia - Plain Packaging Measures [7.2294]-[7.2392].

192 Tobacco Plain Packaging Act 2011 (Cth) s 3; Explanatory Memorandum, Tobacco Plain Packaging Bill 2011 (Cth), 15.

193 Australia - Plain Packaging Measures [7.2398]-[7.2411]

${ }^{194}$ Australia - Plain Packaging Measures [7.2406], [7.2588]

${ }^{195} \mathrm{Yu}$ also identifies other human rights with links to the object and purpose of TRIPS: Yu (n53) 1037.

${ }^{196}$ Frankel has previously characterised TRIPS provisions where 'the treaty language alone does not determine the scope of the provision' as open textured: Frankel (n 45) 421.

197 Australian Government Productivity Commission, Intellectual Property Arrangements (23 September 2016) <http://www.pc.gov.au/inquiries/completed/intellectual-property/report/intellectual-property.pdf $>$ accessed 22 November 2018, 13.

${ }^{198}$ Australia - Plain Packaging Measures [7.2595-6], [7.2604]
} 


\subsection{The importance of Articles 7 and 8}

The Panel recognised the explicit linkage of the object and purpose of TRIPS to article 7 and 8 in the Doha Declaration and identified the Doha Declaration as a subsequent agreement to TRIPS. ${ }^{199}$ As a subsequent agreement the Doha Declaration is relevant to interpretation of provisions of TRIPS such as Article $20 .^{200}$ This suggests the importance of recognising the principles and objectives they identify, where they are relevant to interpretation. Australia's approach of emphasising the object and purpose of protection of intellectual property rights in TRIPS may correspond with wellconsidered legal strategy. However, Australia's approach risked diminishing other considerations found in the preamble, Article 7 and Article 8 that are relevant to both object and purpose and the issues raised in a dispute. Arguably, the limited interpretation of Articles 7 and 8 of TRIPS by the dispute settlement bodies has made it difficult for some countries to use them confidently when they wish to rely on them in interpretation of the compatibility of domestic legislation with TRIPS ${ }^{201}$ but the Panel Decision in the WTO Disputes provides further, significant interpretation. ${ }^{202}$ This is particularly important in cases like tobacco plain packaging legislation where the multiplicity of disputes can be characterised as a coordinated attack on the introduction of plain packaging legislation worldwide. Together with Philip Morris' attack on Uruguay's less restrictive tobacco legislation, the disputes regarding plain packaging legislation have been cited as barriers to the introduction of this legislation in other countries. ${ }^{203}$ In this way the actions of tobacco companies can have a chilling regulatory impact on efforts to address the link between package advertising and tobacco consumption. ${ }^{204}$

This has special significance in the context of the right to health because states' obligations include the responsibility to protect individuals against the actions of third parties that constitute threats to health. Evidence suggests that tobacco companies are the type of third parties that States need to protect against. ${ }^{205}$ Problematically, where there are potential conflicts between fragmented human rights obligations and intellectual property obligations, attacks on legislation in multiple, expensive dispute resolution fora can give strong economic incentives for states to give primacy to their intellectual property obligations. Recognising the importance of Article 7 and Article 8 arguments and linking them to human rights obligations will not specifically address the problems posed by plurilateral and bilateral trade agreements. ${ }^{206}$ However, such arguments may at least partially mitigate the potentially chilling impact of non-state actors on human rights supportive legislation to the extent that they build a culture in the WTO of recognising the links between human rights and the object and purpose of TRIPS. Frankel has identified the potential utility of non-violation complaints to address the cumulative negative impact of TRIPS plus standards found in bilateral

\footnotetext{
${ }^{199}$ Australia - Plain Packaging Measures [7.2407]-[7.2411].

200 VCLT art 31(3)(a).

${ }^{201}$ Susy Frankel 'Some Consequences of Misinterpreting the TRIPS Agreement' (2009) 1 WIPO Journal 35, 4142.

${ }^{202}$ Australia - Plain Packaging Measures [7.2413]-[7.2431].

${ }^{203}$ Lukasz Gruszczynski 'Australian Plain Packaging Law, International Litigation and Regulatory Chilling Effect' [2014] European Journal of Risk Regulation 242, 244; Eric Crosbie, George Thomson 'Regulatory Chills: Tobacco Industry Legal Threats and the Politics of Tobacco Standardised Packaging in New Zealand'. 2018, 131(14) NZMA 1473.

${ }^{204}$ See Jennifer L Tobin, 'The Social Cost of International Investment Agreements: The Case of Cigarette Packaging' (2018) 32(2) Ethics \& International Affairs 153.

205 Crow (n 112) 211; Dresler and Marks (n 112) 633, 644.

${ }^{206}$ Some of these complex issues are considered in Cynthia Ho 'Sovereignty Under Siege: Corporate Challenges to Domestic Intellectual Property Decisions' (2015) 30(1) Berkeley Technology Law Journal 213 and Rochelle Dreyfuss and Susy Frankel, 'From Incentive to Commodity to Asset: How International Law is Reconceptualizing Intellectual Property' (2015) 36 Michigan Journal of International Law 557, 565-6.
} 
trade agreements on the structure and purpose of TRIPS. ${ }^{207}$ If human rights objectives are recognised as relevant to Article 7 and 8 and the object and purpose of TRIPS, this may also a relevant consideration if non-violation complaints are used to address the impact of bilateral and plurilateral trade agreements in the future.

\subsection{Relevant rules of international law to interpretation of 'unjustifiably'}

The relevance of human rights to interpretation of Article 20 in the WTO Disputes can be strengthened by analysis of relevant rules of international law applicable to some or all parties to the dispute. VCLT Article 31(3)(c) engages separate consideration of relevance and applicability. One of the reasons that directly addressing the relevance of articles 7 and 8 to interpretation of TRIPS is important is that the object and purpose of TRIPS can assist our understanding of what 'relevant rules of international law applicable between the parties' can guide treaty interpretation. ${ }^{208}$ Human right to health obligations bind Australia and are relevant to the object and purpose of TRIPS so it is arguably not necessary to reference Article $31(3)(c) .{ }^{209}$ However, identifying treaties which bind the relevant parties reaffirms the existence of these potentially competing international obligations and that dispute resolution fora should recognise and address these obligations. ${ }^{210}$

The relevant international laws applicable to interpreting Article 20 pursuant to Article 31 of the VCLT can depend on the interpretation of 'parties' in Article 31(3)(c). ${ }^{211}$ This can refer to the parties in dispute or all of the parties to the TRIPS Agreement or it recognise a balance between obligations that bind one party to the dispute and a significant number of WTO members ${ }^{212}$ There is dispute as to whether when these rules are external to the agreement being interpreted, they must be binding on all of the parties to the agreement, or, in cases of dispute, to parties who are in dispute with each other, or simply for at least one of the parties to the agreement or dispute. ${ }^{213}$ The approach that other rules can be relevant if the parties to the dispute will be bound by them contributes to systemic integration of international law, although that integration can be limited to agreements between the overlapping parties. ${ }^{214}$ These rules guide our understanding of how the protection and enforcement of intellectual property contributes to the relevant balance of rights and obligations recognised in Article 7 of TRIPS.

Section 4 has identified the right to health as the most important human right engaged by plain packaging legislation. Right to health obligations can be found in ICESCR and other human rights agreements, including the Convention on the Rights of the Child. Arguably the FCTC interprets right to health obligations found in ICESCR that are relevant to health obligations related to the

\footnotetext{
${ }^{207}$ Susy Frankel, 'Challenging Trips-Plus Agreements: The Potential Utility of Non-Violation Disputes' (2009), 12(4) Journal of International Economic Law 1023, 1043.

${ }^{208}$ VCLT art 31(3) guides the treaty interpreter to consider 'any relevant rules of international law applicable between the parties.'

${ }^{209}$ McLachlan notes that use of VCLT art 31(3)(c) is part of a broader process of interpretation and 'reference to external sources of international law may be helpful may be better resolved as part of an enquiry into either the ordinary meaning of the words in their context, or the object and purpose of the treaty:' Campbell McLachlan, 'The Principle of Systemic Integration and Article 31 (3)(c) of the Vienna Convention.' (2005) 54(2) International \& Comparative Law Quarterly 279, 291.

${ }^{210}$ Ruse-Khan proposes a conflict rule of integration approach that recognises the value of a forum which can best integrate other laws: Ruse-Khan (n 33).

${ }^{211} \mathrm{Cf}$ Benn McGrady who emphasises relevance: Benn McGrady, Trade and Public Health: The WTO, Tobacco, Alcohol, and Diet, Trade and Public Health (Cambridge University Press 2011) 45-78.

${ }^{212}$ Ruse-Khan (n 1) 143.

${ }^{213}$ See, for example, the different approaches taken by McGrady and Ruse-Khan. See McGrady (n 211) 45-78;

Ruse-Khan (n 1) 142.

${ }^{214}$ Ruse-Khan (n 1) 143.
} 
consumption of tobacco. ${ }^{215}$ Compliance with certain obligations in each of these agreements constitutes a justification for restrictions on trade mark rights that can guide treaty interpretation as to the meaning of 'unjustifiably' in each of the disputes. The table below sets out the status of each of the parties in relation to each of these agreements.

\begin{tabular}{|l|l|l|l|}
\hline Party & $\begin{array}{l}\text { Convention on } \\
\text { the Rights of } \\
\text { the Child }\end{array}$ & ICESCR & FCTC \\
\hline Australia & Ratified & Ratified & Ratified \\
\hline Honduras & Ratified & Ratified & Ratified \\
\hline Cuba & Ratified & Signed & Signed \\
\hline Indonesia & Ratified & Acceded & Not signed \\
\hline $\begin{array}{l}\text { Dominican } \\
\text { Republic }\end{array}$ & Ratified & Acceded & Not signed \\
\hline
\end{tabular}

The FCTC only applies to the dispute between Australia and Honduras but it is quite widely ratified amongst members. The Convention on the Rights of the Child is an agreement that binds all of the parties to the disputes and is very widely ratified. ICESCR is a relevant agreement in disputes between Australia and Honduras, Indonesia and the Dominican Republic, respectively. Although Cuba is not bound by ICESCR as a signatory that has not yet ratified the agreement, it is obliged 'to refrain, in good faith, from acts that would defeat the object and the purpose of the treaty. ${ }^{.216} \mathrm{It}$ is also relevant that, at the time of signing, Cuba's foreign minister stated that Cuba had always applied the principles enshrined in the agreement. ${ }^{217}$ Arguably, the provisions of ICESCR could constitute a relevant rule of customary international law that which would also be relevant to the dispute between Australia and Cuba, pursuant to Article 31(3)(c). ${ }^{218}$

Where international agreements outside the WTO are relevant to both the dispute and the object and purpose of TRIPS, considerations of systemic integration are engaged when they also bind parties to the dispute. Ruse-Khan argues that interpretation of the term parties should arguably favour a normative environment which binds a significant number of other WTO members as opposed to smaller normative environments such as bilateral investment treaties. ${ }^{219}$ The decisions of the Appellate Body in EC-Aircraft suggest that there should be a balance between agreements that balance all WTO members and agreements that bind individual members. ${ }^{220}$ Benn McGrady characterises the approach of requiring parties to the dispute to be parties to extraneous agreements for them to be relevant as a restrictive approach to interpretation of Article 31(3)(c). ${ }^{221}$ He argues that a more appropriate approach for WTO disputes is to consider rules of international law relevant to the issues in dispute. ${ }^{222}$ If this broader approach were taken, it is arguable that Convention on the Rights of the Child, ICESCR and FCTC rights are relevant laws.

\footnotetext{
${ }^{215}$ Cabrera and Gostin (n 155) 293.

${ }^{216}$ VCLT art 18.

217 James C. McKinley Jr, 'Cuba signs 2 Human Rights Treaties' New York Times (New York, 29 February 2008).

${ }^{218}$ Ruse-Khan (n 1) 35.

219 ibid, 143.

${ }^{220}$ European Communities - Measures Affecting Trade in Large Civil Aircraft Appellate Body Report (18 May 2011, WT/DS316/AB/R), 363.

221 Benn McGrady (n 211) 45-78.

222 ibid. See Benn McGrady 'Fragmentation of International Law or Systemic Integration of Treaty Regimes: ECBiotech Products and the Proper Interpretation of Article 31 (3)(c) of the Vienna Convention on the Law of Treaties' (2008) 42 Journal of World Trade 589.
} 


\section{CONCLUDING OBSERVATIONS}

Human rights obligations engaging the right to health can justify plain packaging legislation and can be relevant to the interpretive tools of object and purpose and Article 31(3)(c). These concerns are relevant to interpretation of the term 'unjustifiably' even if they are not necessary public health measures. Accepting the relevance of the right to health to the WTO disputes, interpretation of that right by CESCR raises additional relevant considerations. The right to health requires states to recognise the importance of international cooperation and assistance between states to permit all states to recognise minimum core obligations identified by CESCR in relation to the right. Related to this is the obligation of state parties to 'ensure that their actions as members of international organizations take due account of the right to health. ${ }^{223}$ Arguably the WTO members who are bringing these actions are not taking due account of the right to health. CESCR interprets violations of the obligation to respect the right to health to include 'the failure of the State to take into account its legal obligations regarding the right to health when entering into bilateral or multilateral agreements with other States, international organizations and other entities, such as multinational corporations. ${ }^{224}$ If Articles 7 and 8 are not sufficiently broad to recognise right to health obligations this obligation might be engaged. Problematically, limited emphasis on these provisions limits interpretation of them by WTO dispute settlement bodies. This means that it is difficult to understand how they can be used to protect human rights. This chapter demonstrates that there are interpretative justifications for considering human rights concerns in IP-related WTO disputes. Recognition of this may permit greater systemic integration of international laws for intellectual property and for human rights and strengthen arguments that the WTO is the venue for dispute resolution best equipped to address conflicts between intellectual property and human rights.

${ }^{223}$ General Comment 14 [39]

${ }^{224}$ General Comment 14 [50] 


\section{Abstract}

This chapter considers the object and purpose of TRIPS and the Paris Convention and uses Australia's tobacco plain packaging legislation to argue that human rights obligations can be relevant to the interpretation of trade mark provisions in the World Trade Organization. Australia's tobacco plain packaging legislation has been unsuccessfully contested as inconsistent with multiple provisions of TRIPS in the World Trade Organization. A key issue was whether the requirements unjustifiably encumbered the use of tobacco-related trade marks in the course of trade. Although they were not considered in the dispute, a number of human rights concerns relevant to the justification for plain packaging legislation can also be relevant to the object and purpose of TRIPS and interpretation of relevant terms in the agreement. These concerns are important but states must recognise and articulate the relevance of human rights to legislation for them to be considered in future disputes.

Key words: human rights, plain packaging, trade marks

ORCID $\underline{0000-0002-4946-5437}$ 